\section{Mineral Nutrition of Prunus Rootstocks: Leaf Concentrations and Diagnosis by Vector Analysis}

\author{
Antonio L. García, ${ }^{1}$ Jesús Gallego, Vicenta Fuentes, Nuria Nicolás, and \\ Ramón Madrid \\ Departamento Química Agrícola, Facultad de Química, Universidad de Murcia \\ P.O. Box 4021 Murcia, Spain
}

Additional index words. fertilization, irrigation, phosphorus

\begin{abstract}
The effects of different levels of phosphorus fertilization and water provision on the mineral nutrition of two clonal rootstocks of Prunus were studied. Two-year-old Prunus seedlings, Hybrid GF677 (Prunus persica $\times$ Prunus amygdalus) $(\mathrm{PH})$ and Pollizo Puebla de Soto 101 (Prunus insititia) (PI) were planted in an uncultivated calcareous soil (a Xeric torriorthent derived from marl) under greenhouse conditions. They were drip irrigated with subterranean water of slightly alkaline $\mathrm{pH}(7.63), \mathrm{EC} 0.88 \mathrm{dS} \cdot \mathrm{m}^{-1}$, with a low chloride and high sulphate content. The experiment lasted two annual cycles. In October of the second year the leaf nutrient concentration and dry weight of the total leaf weight were determined in four trees of each combination of rootstock $\times$ irrigation level $\times$ fertilization treatment. The nutritive state of these trees was analyzed by vector analysis. The results point to a highly significant influence of the rootstock nature on the leaf concentrations of most nutrients. Very low $\mathrm{Zn}$ and $\mathrm{Cu}$ concentrations were recorded on both rootstocks, for both irrigation levels and several fertilizing treatments. Vector analysis confirmed the $\mathrm{Cu}$ deficiency resulting from several of the fertilizing treatments and both irrigation levels in $\mathrm{PH}$ rootstocks.
\end{abstract}

Prunus cultivation, homogenizing plantations and permitting higher densities as a result of the less excessive vigor (Rubio and Socías i Company, 1991). Among clonal rootstock, hybrid variants are becoming the norm in stone fruit species of the genus Prunus L for commercial plantations (Rubio and Socías i Company, 1991). Such aspects as the influence of rootstock type on the absorption of different minerals, productivity, root development, salt tolerance and root asphyxia, besides resistance to drought, have contributed to the expansion in the use of hybrid rootstock (Gómez Aparisi, 1991).

The root system has a strong influence on the chemical composition of plants, although the nutrient absorption capacity is only part of a wealth of interactions which affect the levels of mineral elements in plant tissues (Wutscher, 1989). Most studies on the effect of the rootstock on mineral nutrition in trees are based on leaf analyses (Brown and Cuming, 1989; Said et al., 1993), despite the fact that all the plant tissues are involved (Holevas et al, 1985). Leaf element levels depend on absorption and transport processes, in which the rootstock has been seen to play an important role in the levels of micronutrients (Gómez Aparisi, 1991).

In an attempt to develop a practical criterion for use in differential fertilization studies, vector analysis was developed for nutritional diagnosis purposes (Timmer and Stone, 1978; Timmer and Amstrong, 1987; Timmer and Teng, 1990). Vector diagnosis involves

Received for publication 11 Mar. 2005. Accepted for publication 10 May 2005. The authors thank Philip Thomas for checking the English.

${ }^{1}$ Corresponding author. comparing nutrient (compares) concentration, nutrient content, and biomass of plants in a graphic format known as a vector nomogram. Plant tissues sampled are usually compared to a control or reference (R). Based on the magnitude and direction of vectors describing response to treatment in terms of these three variables, analyses can be used to diagnose consumption, excess and dilution.

In this study we examine the mineral nutrition of two Prunus rootstock by determining leaf levels of elements and diagnose this nutrition by vector analysis.

Plant material and experimental site. Two-year-old Prunus, Hybrid GF677 (Prunus persica $\times$ Prunus amygdalus $),(\mathrm{PH})$ and Pollizo Puebla de Soto (Prunus insititia), (PI), which were in accordance with current Spanish legislation concerning varietal purity and sanitary state, were used. In winter, 2000, these were planted in 250-L plastic containers containing $350 \mathrm{~kg}$ of an uncultivated soil (Xeric torriorthent derived from marl), 32.6\% sand, $27 \%$ clay, low fertility $(\mathrm{CEC}=9.21 \mathrm{meq} / 100$ $1.71 \mathrm{mg} \cdot \mathrm{kg}^{-1}$ (Watanabe and Olsen, 1963), total $\mathrm{CaCO}_{3}=58.3 \%$, active $\mathrm{CaCO}_{3}=10.2 \%$, bulk density $=1.40 \mathrm{~kg} \cdot \mathrm{m}^{-3}$ ) a quantity considered sufficient for the roots to develop during the 2 years that it was envisaged that the experiment would last. The trees were grown in a plastic greenhouse to avoid any meteorological inclemency in the Segura River valley, $38^{\circ} 5^{\prime} \mathrm{N}$, $1^{\circ} 4^{\prime} \mathrm{W}, \mathrm{T} \max / \min =36 / 16^{\circ} \mathrm{C}, \% \mathrm{RH} \max / \mathrm{min}$ $=70 / 50$, S.E. Spain. nutrient status: sufficiency, deficiency, luxury

\section{Material and Methods} $\mathrm{g}, \mathrm{N}_{\text {total }}=0.04 \%-$ only organic, available $\mathrm{P}=$
The recipients were arranged in 12 rows of 20 containers with sufficient room between them to allow the canopy to grow. A drip line was run across all the containers with one self-compensating emitter in the center of each container. Half the emitters provided 4 $\mathrm{L} \cdot \mathrm{h}^{-1}$ and the other half $2 \mathrm{~L} \cdot \mathrm{h}^{-1}$, flow rates that were periodically checked throughout the experimental with coefficients in excess of $92 \%$ always being obtained. Eight tensiometers of $40 \mathrm{~cm}$ length were installed at random, 4 for each irrigation treatment to assess soil humidity, and water was added when measurements above $25 \mathrm{cb}$ were recorded in any of them. The irrigation time for both sets of emitters ( 2 and $\left.4 \mathrm{~L} \cdot \mathrm{h}^{-1}\right)$ was the same so that half of the trees received exactly double amount of water. At the end of each irrigation period it was checked that the tensiometer readings were $0 \mathrm{cb}$. The water used came from a well and had a slightly alkaline $\mathrm{pH} 7.63, \mathrm{EC}=0.88 \mathrm{dS} \cdot \mathrm{m}, \mathrm{Cl}^{-}=1.50$ $\mathrm{mmol} \cdot \mathrm{L}^{-1}, \mathrm{SO}_{4}^{-2}=2.60 \mathrm{mmol} \cdot \mathrm{L}^{-1}, \mathrm{HCO}^{-}=$ $2.15 \mathrm{mmol} \cdot \mathrm{L}^{-1}, \mathrm{Ca}^{+2}=1.80 \mathrm{mmol} \cdot \mathrm{L}^{-1}, \mathrm{Mg}^{3}$ $=2.20 \mathrm{mmol} \cdot \mathrm{L}^{-1}, \mathrm{Na}^{+}=0.80 \mathrm{mmol} \cdot \mathrm{L}^{-1}$ no potassium or carbonates were detected. The experiment lasted two annual cycles.

Experimental design and treatments. After an adaptation period (February to April, 2000), during which the plants only received water, $50 \mathrm{~mL}$ of monoamonic phosphate solution at different concentrations were applied at the same time as the irrigation water to the drip zone. Five blocks of four trees in each row were designated and each block received a given fertilizer dose: F1, F2, F3, F4, and F5. Treatment $\mathrm{F} 1$ each plant received $\left(\mathrm{NH}_{4}\right) \mathrm{PO}_{4} \mathrm{H}_{2}$ at $0.124 \mathrm{~g}$, which was doubled for F2, tripled for F3 and so forth. During the first year each treatment received 12 applications of fertilizer, which was increased to 18 applications during the second year in the case of F3, F4, and F5. Blocks F2 and F1 received 11 applications in an attempt to ensure that the leaf concentrations of phosphorus in the trees of these treatments were not as high as the levels recorded in the periodic controls carried out during the first year of the experiment. The experimental design, then, consisted of twelve trees per combination of three variables: rootstock type, irrigation level, and fertilizer treatment.

Leaf analysis controls were made in four trees from each of the above mentioned combinations, of which we only refer to the control carried out in the October of the second year. The leaves for analysis were taken in each case from the central part of the branches and washed in deionizer water with non ionic detergent before being dried to constant weight in a forced air oven at $65{ }^{\circ} \mathrm{C}$. They were then triturated, passed through a $0.3-\mathrm{mm}$ mesh and dried at $105{ }^{\circ} \mathrm{C}$. In the case of the October sample, the dry weight of the total leaf weight of the sampled trees was also determined.

The $\mathrm{N}$ content was determined by the Kjeldahl method(Bremner, 1965) modified at a semimicro scale with $50 \mathrm{mg}$ of dry leaf sample. Phosphorus was determined colorimetrically by measuring the yellowness of the phosphovanadate complex (Watanabe and Olsen, 1963). The remaining nutrients were determined by atomic absorption spectrometry $(\mathrm{Ca}, \mathrm{Mg}, \mathrm{Fe}$, 
$\mathrm{Mn}, \mathrm{Zn}$ and $\mathrm{Cu}$ ) or emission spectrometry ( $\mathrm{Na}$ and $\mathrm{K}$ ) after humid mineralization with a nitric-perchloric mixture of dry leaf material $(1 \mathrm{~g})$.

A multifactorial variance analysis was applied to the data obtained to ascertain whether the differences observed in the leaflevels of the elements analysed were due to one or more of the different variables: rootstock, irrigation or fertilisation. Differences between treatments means for each rootstock and irrigation levels were compared using the Duncan's multiple range test.

Vector analysis technique. The vector analysis technique (Timer andAmstrong, 1987; Timer and Teng, 1990; Timmer and Stone, 1978) permits simultaneous multielement comparisons of needle dry weight, nutrient concentration and nutrient content of plant components. The technique is used to better understand plant and soil interrelationships with special emphasis on soil fertility and tree mineral nutrition.

The construction of the vector diagram is in a graphic format known as a vector nomogram. In brief, mean concentrations (y-axis) for each mineral element are plotted against corresponding mean contents(x-axis). Because concentration is a ratio between content and biomass, biomass represents the inverse of the slope factor, and the plotted data will automatically lie on diagonal lines corresponding to the mean biomass (z-axis) for each element. The data can be plotted in the form of absolute or relative values. In the latter case, values for each treatment are calculated by dividing their concentrations, contents and biomass by the corresponding values for the reference sample for which $\mathrm{x}=\mathrm{y}=\mathrm{z}=100$. The advantage of using absolute values is that standard deviations or standard errors for concentrations and contents can be shown on a vector diagram. Relative values, on the other hand, allow results for several compounds or experiments to be presented on the same graph. Vector diagrams can be based either on plant part or on whole-plant estimates of biomass, content and concentration. The magnitude and direction of the vectors are used to interpret the effect of the treatment.

Based on the magnitude and direction of vectors describing response to treatment in terms of these three variables, analyses can be used to diagnose nutrient status: sufficiency, deficiency, luxury consumption, toxicity, antagonism and are particularly effective in detecting nutrient interactions. All the data are expressed on a leaf dry weight basis (Fig. 1).

\section{Results}

Element concentrations in leaves. The following tables depict the mean leaf levels of the different elements for each of the treatments designated above. Each value is the mean of four repetitions.

Table 1 shows the mean $\mathrm{N}, \mathrm{P}, \mathrm{Ca}, \mathrm{Mg}, \mathrm{K}$, and $\mathrm{Na}$ concentrations. As it can be seen, the levels of all the elements were influenced by the rootstock used, with $\mathrm{Ca}, \mathrm{Mg}$, and $\mathrm{Na}$ levels being highest on the $\mathrm{PH}$ and $\mathrm{P}, \mathrm{N}$, and $\mathrm{K}$ on the PI. Although the irrigation treatment had a statistically significant effect on $\mathrm{N}, \mathrm{Mg}$, and $\mathrm{K}$, for the other elements determined the leaf concentrations were similar on both rootstocks regardless of irrigation level.

Fertilizer treatment did not seem to much affect element concentration, not even in the case of $\mathrm{P}$ and $\mathrm{N}$, which were the principal elements involved in the differential fertilizer treatments.

Table 2 shows the concentrations of $\mathrm{Zn}$, $\mathrm{Mn}, \mathrm{Fe}$, and $\mathrm{Cu}$ in leaves. The rootstock has a strong influence on the first of these elements since the concentrations in leaves on the $\mathrm{PH}$ rootstock are higher than those on PI. Fertilizer treatment also has an effect since higher concentrations of the fertilizer led to lower concentrations of $\mathrm{Zn}$. Irrigation had no effect. Mn was not clearly affected by any of the variables. In the case of Fe, there were significant differences in the interaction rootstock $\times$ treatment, with lower values being recorded on PH of treatment F2 and PI of F1. The $\mathrm{Cu}$ values were lower on PH than on PI at both irrigation levels, the interactions rootstock $\times$ irrigation and rootstock $\times$ fertilization being statistically significant.

Table 1. Nutrient concentration in leaves (percent of leaf dry weight) recorded for the final sampling (October of the second year, 2001). Each value is the mean of four repetitions

\begin{tabular}{|c|c|c|c|c|c|c|}
\hline Treatment $^{\mathrm{z}}$ & $\mathrm{P}$ & $\mathrm{N}$ & $\mathrm{Ca}$ & $\mathrm{Mg}$ & $\mathrm{K}$ & $\mathrm{Na}$ \\
\hline$\overline{\mathrm{PH} 4 \mathrm{~F} 1}$ & 0.27 & $1.89 \mathrm{~d}^{\mathrm{y}}$ & 4.98 & 0.78 & $1.67 \mathrm{bc}$ & $0.017 \mathrm{~b}$ \\
\hline PH4F2 & 0.18 & $1.69 \mathrm{e}$ & 4.08 & 0.83 & $0.97 \mathrm{~d}$ & $0.017 \mathrm{~b}$ \\
\hline PH4F3 & 0.23 & $2.40 \mathrm{~b}$ & 3.58 & 0.76 & $1.55 \mathrm{c}$ & $0.014 \mathrm{c}$ \\
\hline PH4F4 & 0.20 & $2.56 \mathrm{a}$ & 3.84 & 0.73 & $1.82 \mathrm{~b}$ & $0.015 \mathrm{c}$ \\
\hline PH4F5 & 0.26 & $2.15 \mathrm{c}$ & 4.57 & 0.81 & $2.35 \mathrm{a}$ & $0.019 \mathrm{a}$ \\
\hline Means & 0.23 & 2.14 & 4.21 & 0.78 & 1.67 & 0.016 \\
\hline Anova & NS & * & NS & NS & $* *$ & $*$ \\
\hline PH2F1 & $0.24 \mathrm{~b}$ & $1.72 \mathrm{~d}$ & 6.68 & 0.71 & 0.72 & 0.037 \\
\hline PH2F2 & $0.62 \mathrm{a}$ & $1.47 \mathrm{e}$ & 5.29 & 1.00 & 1.04 & 0.015 \\
\hline PH2F3 & $0.18 \mathrm{~b}$ & $2.28 \mathrm{a}$ & 4.37 & 0.88 & 1.08 & 0.021 \\
\hline PH2F4 & $0.26 \mathrm{~b}$ & $2.06 \mathrm{c}$ & 4.13 & 0.82 & 1.31 & 0.017 \\
\hline PH2F5 & $0.20 \mathrm{~b}$ & $2.19 \mathrm{~b}$ & 5.17 & 0.88 & 1.58 & 0.025 \\
\hline Means & 0.30 & 1.94 & 5.13 & 0.86 & 1.15 & 0.023 \\
\hline Anova & $*$ & $* *$ & NS & NS & NS & NS \\
\hline PI4F1 & 0.33 & 2.23 & 1.94 & $0.48 \mathrm{~b}$ & 3.91 & $0.012 \mathrm{~d}$ \\
\hline PI4F2 & 0.34 & 2.12 & 1.86 & $0.45 \mathrm{~b}$ & 4.22 & $0.019 \mathrm{a}$ \\
\hline PI4F3 & 0.40 & 2.37 & 2.01 & $0.70 \mathrm{a}$ & 3.62 & $0.014 \mathrm{c}$ \\
\hline PI4F4 & 0.32 & 2.39 & 2.48 & $0.49 \mathrm{~b}$ & 3.43 & $0.014 \mathrm{c}$ \\
\hline PI4F5 & 0.38 & 2.16 & 1.91 & $0.54 \mathrm{~b}$ & 3.71 & $0.017 \mathrm{~b}$ \\
\hline Means & 0.35 & 2.25 & 2.04 & 0.53 & 3.78 & 0.015 \\
\hline Anova & NS & NS & NS & * & NS & $* *$ \\
\hline $\mathrm{PI} 2 \mathrm{~F} 1$ & $0.31 \mathrm{~b}$ & 2.15 & 1.69 & $0.48 \mathrm{c}$ & 3.73 & $0.011 \mathrm{~b}$ \\
\hline $\mathrm{PI} 2 \mathrm{~F} 2$ & $0.48 \mathrm{a}$ & 2.18 & 1.92 & $0.53 \mathrm{bc}$ & 4.29 & $0.016 \mathrm{a}$ \\
\hline $\mathrm{PI} 2 \mathrm{~F} 3$ & $0.33 \mathrm{~b}$ & 2.15 & 2.42 & $0.68 \mathrm{a}$ & 4.00 & $0.016 \mathrm{a}$ \\
\hline PI2F4 & $0.42 \mathrm{a}$ & 2.29 & 2.17 & $0.58 \mathrm{~b}$ & 3.91 & $0.016 \mathrm{a}$ \\
\hline $\mathrm{PI} 2 \mathrm{~F} 5$ & $0.30 \mathrm{~b}$ & 2.16 & 2.00 & $0.66 \mathrm{a}$ & 4.02 & $0.014 \mathrm{a}$ \\
\hline Means & 0.37 & 2.19 & 2.04 & 0.59 & 3.99 & 0.015 \\
\hline Anova & * & NS & NS & * & NS & $*$ \\
\hline $\mathrm{R}$ & $* *$ & $* *$ & $* * *$ & $* * *$ & $* * *$ & $* * *$ \\
\hline I & NS & $*$ & NS & * & * & NS \\
\hline FT & $*$ & $* * *$ & NS & * & $*$ & $* * *$ \\
\hline $\mathrm{R} \times \mathrm{I}$ & NS & NS & NS & NS & $* * *$ & $* *$ \\
\hline $\mathrm{R} \times \mathrm{FT}$ & NS & $* *$ & NS & * & $* * *$ & $* * *$ \\
\hline $\mathrm{I} \times \mathrm{FT}$ & $* *$ & NS & NS & NS & $* * *$ & $* *$ \\
\hline$\underline{\mathrm{R} \times \mathrm{I} \times \mathrm{FT}}$ & NS & NS & NS & NS & NS & NS \\
\hline
\end{tabular}

${ }^{2} \mathrm{PH}=$ Prunus persica $\times$ Prunus amygdalus $; \mathrm{PI}=$ Prunus insititia $; 4,2=$ Irrigation time $(\mathrm{h}) ; \mathrm{F} 1-\mathrm{F} 5(\mathrm{FT})$ $=$ fertilizer treatment; $\mathrm{R}=$ rootstock type; $\mathrm{I}=$ irrigation level. In the upper part and for each rootstock, the probability that the difference between means may be due to chance is included.

yThe means followed by different letters are significantly different at $0.05 \%$ probability by Duncan's multiple range test.

NS,*,**,***N Nonsignificant or significant at $p<0.05,0.01$, or 0.001 . The means followed by different letters are significance of the influence of the different factors and their interactions are recorded for each element. The means followed by different letters are significantly different at $0.05 \%$ probability by Duncan's multiple range test. 
Table 2. Nutrient concentrations in leaves (ppm over leaf dry weight) and leaf dry weight (g) during final sampling (October 2001).

\begin{tabular}{|c|c|c|c|c|c|}
\hline Treatment $^{z}$ & $\mathrm{Zn}$ & $\mathrm{Mn}$ & $\mathrm{Fe}$ & $\mathrm{Cu}$ & Dry wt \\
\hline PH4F1 & 19.0 & 94.8 & 77.8 & 11.1 & $200.3 \mathrm{c}^{y}$ \\
\hline PH4F2 & 14.8 & 85.1 & 48.4 & 5.06 & $91.3 \mathrm{c}$ \\
\hline PH4F3 & 14.5 & 108.1 & 81.8 & 10.1 & $558.0 \mathrm{~b}$ \\
\hline PH4F4 & 13.3 & 130.7 & 71.1 & 6.7 & $659.7 \mathrm{ab}$ \\
\hline PH4F5 & 14.5 & 111.4 & 60.9 & 10.1 & $832.2 \mathrm{a}$ \\
\hline Means & 15.2 & 106.0 & 68.0 & 8.6 & 468.3 \\
\hline Anova & NS & NS & NS & NS & ** \\
\hline PH2F1 & 16.0 & $166.7 \mathrm{a}$ & 72.5 & 11.8 & 173.7 \\
\hline PH2F2 & 10.9 & $155.5 \mathrm{a}$ & 69.1 & 18.0 & 226.2 \\
\hline PH2F3 & 8.2 & $69.1 \mathrm{c}$ & 75.1 & 26.9 & 324.1 \\
\hline PH2F4 & 11.4 & $57.3 \mathrm{c}$ & 70.7 & 12.9 & 319.1 \\
\hline PH2F5 & 9.7 & $93.2 \mathrm{~b}$ & 86.8 & 15.8 & 668.3 \\
\hline Means & 11.2 & 108.4 & 74.8 & 17.1 & 342.3 \\
\hline Anova & NS & $* *$ & NS & NS & NS \\
\hline PI4F1 & $33.5 \mathrm{a}$ & 100.4 & 52.8 & 25.9 & 231.8 \\
\hline PI4F2 & $32.3 \mathrm{a}$ & 126.7 & 75.1 & 14.5 & 180.3 \\
\hline PI4F3 & $35.3 \mathrm{a}$ & 112.4 & 69.2 & 18.5 & 121.3 \\
\hline PI4F4 & $23.9 \mathrm{c}$ & 95.9 & 73.0 & 25.3 & 215.3 \\
\hline PI4F5 & $27.9 \mathrm{~b}$ & 74.2 & 60.2 & 12.8 & 197.3 \\
\hline Means & 30.6 & 101.9 & 66.1 & 19.4 & 189.2 \\
\hline Anova & * & NS & NS & NS & NS \\
\hline PI2F1 & 30.1 & 81.5 & 48.5 & 23.6 & 127.7 \\
\hline PI2F2 & 39.5 & 99.1 & 78.7 & 12.8 & 74.7 \\
\hline PI2F3 & 26.6 & 117.9 & 62.3 & 17.7 & 105.7 \\
\hline PI2F4 & 25.9 & 86.5 & 64.5 & 25.0 & 153.0 \\
\hline PI2F5 & 20.2 & 85.4 & 50.6 & 17.8 & 104.7 \\
\hline Means & 28.5 & 94.0 & 60.9 & 19.4 & 113.2 \\
\hline Anova & NS & NS & NS & NS & NS \\
\hline $\mathrm{R}$ & $* * *$ & NS & * & $* * *$ & $* * *$ \\
\hline I & NS & NS & NS & $* *$ & $* *$ \\
\hline FT & ** & NS & NS & * & $* * *$ \\
\hline $\mathrm{R} \times \mathrm{I}$ & NS & NS & NS & ** & NS \\
\hline $\mathrm{R} \times \mathrm{Ft}$ & NS & NS & * & ** & $* * *$ \\
\hline $\mathrm{I} \times \mathrm{Ft}$ & NS & * & NS & NS & NS \\
\hline $\mathrm{R} \times \mathrm{I} \times \mathrm{Ft}$ & NS & $* *$ & NS & NS & * \\
\hline
\end{tabular}

${ }^{\mathrm{2}} \mathrm{PH}=$ Prunus persica $\times$ Prunus amygdalus; $\mathrm{PI}=$ Prunus insititia $; 4,2=$ Irrigation time (h); F1-F5 (FT) $=$ fertilizer treatment; $\mathrm{R}=$ rootstock type; $\mathrm{I}=$ irrigation level.

${ }^{y}$ The means followed by different letters are significantly different at $0.05 \%$ probability by Duncan's multiple range test.

NS, $,, * *, * * * *$ Nonsignificant or significant at $p<0.05,0.01$, or 0.001 . The means followed by different letters are significance of the influence of the different factors and their interactions are recorded for each element.

Dry weight fol iar mass

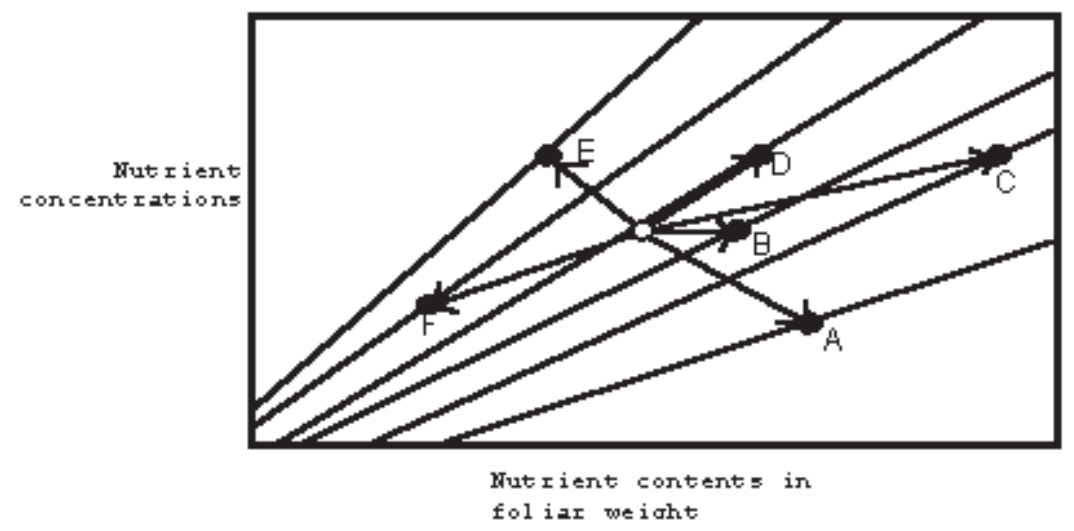

\begin{tabular}{|c|c|c|c|c|c|}
\hline \multirow[b]{2}{*}{ Vertor } & \multicolumn{3}{|c|}{ Charge in: } & \multirow[b]{2}{*}{ Interpretstion } & \multirow[b]{2}{*}{ Di2quosis } \\
\hline & [1]. Dero & Conc. & Cont. & & \\
\hline a & + & - & + & Dilution & non limiting \\
\hline B & + & 0 & + & Sufficiency & Mon limiting \\
\hline c & + & + & + & Deficiency & Limiting \\
\hline D & 0 & + & + & $\begin{array}{l}\text { Superf luous } \\
\text { Consumption }\end{array}$ & Mon toxic \\
\hline $\mathbf{E}$ & - & + & $+6-$ & Excess & Toxic \\
\hline$F$ & - & - & - & Excess & Ant2gonism \\
\hline
\end{tabular}

method for each of the rootstock $\times$ irrigation combinations.

Figure 2 shows that the $\mathrm{PH}$ trees irrigated at $2 \mathrm{~L} \cdot \mathrm{h}^{-1}$ have a lower dry weight in $\mathrm{F} 1$, with pronounced deficiencies of $\mathrm{K}$ and $\mathrm{Cu}$, while $\mathrm{Mn}, \mathrm{Na}, \mathrm{Zn}$, and $\mathrm{Ca}$ are diluted in the other treatments compared with F1. In F2 there is a clear $\mathrm{K}$ deficiency and excess of $\mathrm{P}$ (probably toxic) compared with higher dose treatments.

The vectors corresponding to the $\mathrm{PH}$ rootstock watered at the higher rate (Fig. 3) show lower leaf dry weight values in F2, with deficiencies of $\mathrm{Cu}, \mathrm{K}, \mathrm{Fe}, \mathrm{Mn}, \mathrm{P}$, and $\mathrm{N}$ compared with other treatments. F1 shows a K deficiency with respect to F4 and F5 and a N deficiency wit respect to F3, F4, and F5. The $\mathrm{F} 3, \mathrm{~F} 4$, and $\mathrm{F} 5$ treatments show diluted $\mathrm{Cu}, \mathrm{Ca}$ and $\mathrm{Zn}$ values with respect to $\mathrm{F} 1$

Figure 4 shows the vectors of PI trees watered at $2 \mathrm{~L} \cdot \mathrm{h}^{-1}$. The treatment resulting in the lowest dry weight (F2) clearly produces an intense $\mathrm{Cu}$ deficiency, possibly associated with the excess of P. The rest of the treatments show $\mathrm{Fe}, \mathrm{P}$, and $\mathrm{Zn}$ dilution compared with F2.

As regards the PI trees receiving the higher irrigation level (Fig. 5), F3 produces the lowest dry weight, an excess of $\mathrm{Mg}, \mathrm{Mn}, \mathrm{Fe}, \mathrm{P}$, and a deficiency of $\mathrm{Cu}$. F2 leads to $\mathrm{Cu}$ deficiency and a great excess of $\mathrm{Mn}, \mathrm{Fe}$, and $\mathrm{Na}$. However $\mathrm{Cu}$ deficiency is even more pronounced in $\mathrm{F} 5$, which produces no great excess of any nutrient.

\section{Discussion}

The rootstock used for fruit trees is known to influence nutrient absorption and transport, particularly as regards microelements as opposed to macroelements (Poling and Oberly, 1979).

In our case, $\mathrm{N}$ is affected by the nature of the rootstock (Table 1) and the similar values observed in the PI rootstock trees for the different irrigation and fertilization treatments (Rosati et al., 2000) are probably due to the ease which $\mathrm{N}$ is translocated in these trees with the help of $\mathrm{Cu}$ (Hill et al., 1979; Loneragan et al., 1980) or $\mathrm{Zn}$. The P on PH rootstock seems to be inversely related with $\mathrm{Zn}$ levels (Loneragan et al., 1982), although this relation may be due to the scant translocation which takes place (Cakmak and Marschner, 1987). The levels of $\mathrm{Mg}$ and, especially, of $\mathrm{Ca}$, which is considered to stimulate nutrient absorption by roots (Haynes, 1984) are higher on PH rootstock (Fig. 2), despite the dilution effect caused by the greater vegetative development on this rootstock (Jarrell and Beverly, 1981). The higher values of K on PI imply a high solute load in the xylem (Troyanos et al., 2000), which would encourage the inflow of osmotic water (Lang, 1983), thus increasing the drought tolerance of these trees. This would also contribute to decrease the $\mathrm{Na}$ absorption (Barber, 1984).

Zinc and copper concentrations (Fig. 3) are lower on $\mathrm{PH}$. These trees therefore show a lesser degree of sensitivity to phosphoric fertilization.

Fig. 1. Diagnosis by vector analysis (Timmer and Stone 1978). 
The low Zn content of leaves cannot effectively control the retranslocation of phosphorus towards the roots (Marschner and Cakmak, 1986), although the responses to the different doses of phosphorus used in the experiment are positive and the intensity of irrigation did not affect to phosphorus retranslocation. The PI trees show an effective (internal) regulation

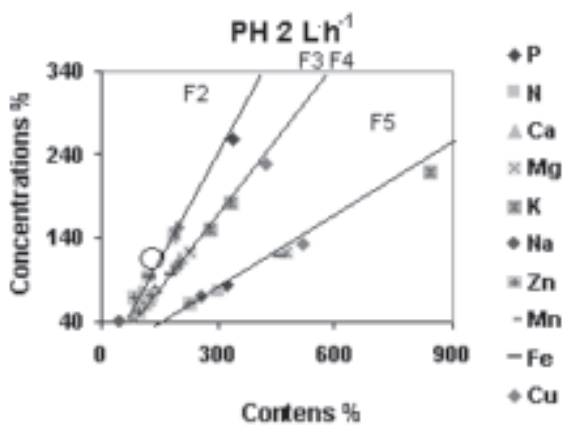

Fig. 2. Leaf vector analysis for $\mathrm{PH}$ rootstock irrigated at $2 \mathrm{~L} \cdot \mathrm{h}^{-1}$.

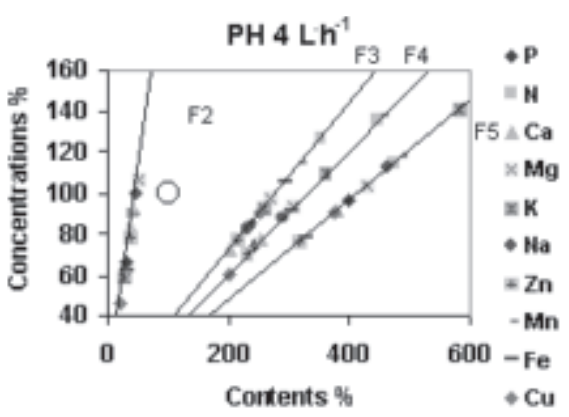

Fig. 3. Leaf vector analysis for PH rootstock irrigated at $4 \mathrm{~L} \cdot \mathrm{h}^{-1}$.

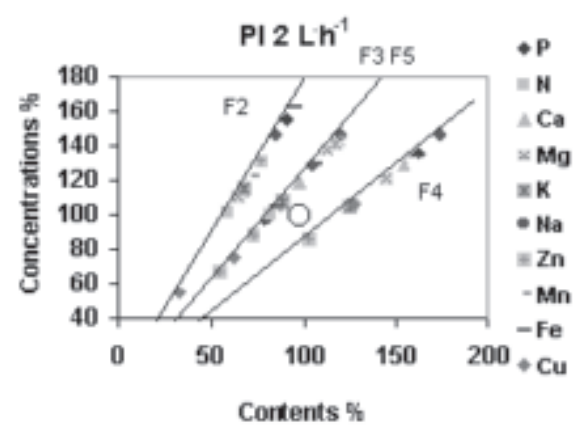

Fig. 4. Leaf vector analysis for PI rootstock irrigated at $2 \mathrm{~L} \cdot \mathrm{h}^{-1}$.

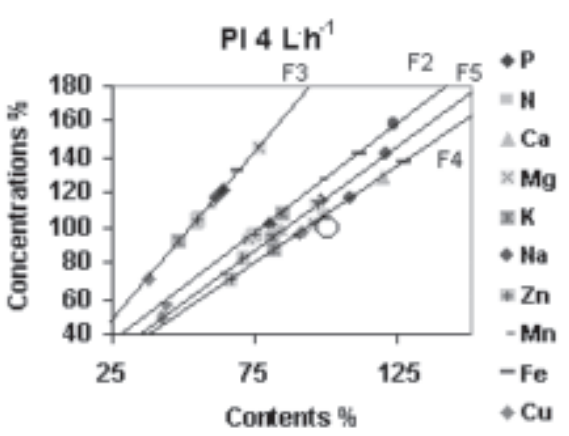

Fig. 5. Leaf vector analysis for PI rootstock irrigated at $4 \mathrm{~L} \cdot \mathrm{h}^{-1}$. of leaf $\mathrm{Zn}$ will mean that root $\mathrm{Zn}$ will vary less in relation to external supply (Lambert et al., 1979). However, $\mathrm{Cu}$ levels, which vary with irrigation and fertilization treatments, seem to reach a retranslocation equilibrium on this rootstock regardless of nitrogen levels (Loneragan et al., 1980).

No variable affected the leaf levels of $\mathrm{Mn}$ on $\mathrm{PH}$ rootstock since in all cases they are higher than the critical value described by many authors (Montañés et al., 1993) and, given the calcareous nature of the soil used in the experiment, there is no risk of excess (Horst and Marschner, 1978). Stone fruit trees growing in calcareous soils like those of the Region of Murcia frequently show signs of iron deficiency although a contributory factor is the presence of phosphate (Kolesch et al., 1987). The PI trees show similar leaf levels for both irrigation treatments and lower values for the F1 and F 5 fertilization treatments in the positive $\mathrm{P} \times \mathrm{F}$ interaction. Despite the small differences in leaf levels, this demonstrates their resistance to chlorosis (Said et al., 1993; Satdler and Lötze, 1990) even when Fe levels are especially low, as in F2.

The $\mathrm{PH}$ trees receiving the lower irrigation level show substantial $\mathrm{K}$ and $\mathrm{Cu}$ deficiencies in F1 (Fig. 2), while in F2 compared with the higher doses (F3, F4, and F5) a deficiency in $\mathrm{K}$ and a toxic excess of $\mathrm{P}$ are manifest. This excess of $\mathrm{P}$ may be explained by the lack of control of the absorption of this element, which may provoke a deficiency of $\mathrm{Zn}$ (Loneragan et al., 1980). The data for $F 3$ and $F 4$ point to the excess of $\mathrm{Cu}$ and $\mathrm{P}$, respectively, which may be interpreted as differentiated responses to the fertilizer treatments received (Romera and Alcántara, 1988).

In Fig. 3, which corresponds to the $\mathrm{PH}$ rootstock receiving the higher quantity of water, the vectors for the different nutrients of treatment F2 show a general deficiency in their values compared with F1. In turn, the value of $\mathrm{N}$ in $\mathrm{F} 1$ represents a deficiency with respect to higher dose treatments, in which $\mathrm{Cu}, \mathrm{Zn}$, and $\mathrm{Ca}$ are substantially diluted. This finding contradicts other reports which point to the simultaneous deficiency of $\mathrm{Zn}$ and $\mathrm{Cu}$ (Teng and Timmer, 1990), which may be explained by the low reference value taken for $\mathrm{Zn}(10.38 \mathrm{ppm})$ since the levels of this element on $\mathrm{PH}$ are low.

In the PI trees receiving the lower dose of water, $\mathrm{Zn}$ deficiency was detected in F3 and F5, which corroborates previous findings as regards the appearance of such a deficiency induced by phosphoric fertilization (Cakmak and Marschner, 1987; Haynes, 1984). Since Zn can control the absorption of phosphorus, its concentration in leaves is affected (Loneragan et al., 1979). Such an effect, which seems to be determined by the regulatory function of $\mathrm{Zn}$ as regards phosphorus retranslocation towards the roots (Cakmak and Marschner, 1987), together with the reduction in growth which accompanies $\mathrm{Zn}$ deficiency, may give rise to toxic effects with respect to $\mathrm{P}$ in plants affected by this deficiency (Loneragan et al., 1979). In the case of PI trees receiving the higher amount of water, $\mathrm{Cu}$ deficiency was detected in F1, F3, and F5 compared with F1, which seems to indicate that there is a relation between $\mathrm{Cu}$ retranslocation and high levels of $\mathrm{N}$ in leaves (Hill et al., 1978).

As a conclusion of what was said before, it is possible to assert that, diagnosis by vector analysis applied to $\mathrm{PH}$ seedlings irrigated with $4 \mathrm{~L} \cdot \mathrm{h}^{-1}$ show clear deficiency of $\mathrm{Cu}$ in $\mathrm{F} 1$ and $\mathrm{F} 2$ treatments, on the other hand, the ones irrigated with $2 \mathrm{~L} \cdot \mathrm{h}^{-1}$ show deficiencies of $\mathrm{Cu}$ and $\mathrm{K}$ in $\mathrm{F} 1$ and $\mathrm{K}$ in $\mathrm{F} 2$. Also an excess of $\mathrm{P}$ appears in both treatments. PI seedlings show a clear deficiency of $\mathrm{Cu}$ in F2 and F5 treatments irrigated with $4 \mathrm{~L} \cdot \mathrm{h}^{-1}$, whilst the ones irrigated with $2 \mathrm{~L} \cdot \mathrm{h}^{-1}$ show an intense deficiency of $\mathrm{Cu}$ associated to a possible toxic excess of $\mathrm{P}$ and a deficiency of $\mathrm{Zn}$ in F5 treatment. Likewise, it is possible to point to that $\mathrm{PH}$ seedlings need less level of fertilizer supply to the growth (foliar weight) than PI seedlings. It confirms the best adaptation of $\mathrm{PH}$ to soil and climate conditions in Southern Spain, where the main problem is the scarcity and cost of good quality irrigation water.

\section{Literature Cited}

Barber, S.A. 1984. Soil nutrient bioavailability. A mechanistic approach. John Wiley and Sons, New York.

Bremner, J.M. 1965. Total nitrogen. In: C.A. Black (ed.). Methods of soil analysis II. Amer. Soc. Agron. Inc. Publ. Madison, Wis.

Brown, S.K. and J.N. Cummins. 1989. Rootstock effect on foliar nutrient concentrations of 'Redhaven' peach trees. HortScience 15:41-43.

Cakmak, I. and H. Marschner. 1987. Mechanism of phosphorus-induced zinc deficiency in cotton. III. Changes in physiological availability of zinc in plants. Physiol. Plantarum 70:13-20.

Gómez Aparisi, J. 1991. Patrones de almendro: comportamiento frente a efectos ambientales adversos. ITEA 3:129-136.

Haynes, R.J. 1984. Lime and phosphate in the soilplant system. Adv. Agron. 37:249-315.

Hill, J., A.D. Robson, and J.F. Loneragan. 1978. The effect of copper and nitrogen supply on the retranslocation of copper in four cultivars of wheat. Austral. J. Agr. Res. 29:925-939.

Hill, J., A.D. Robson, and J.F. Loneragan. 1979. The effect of copper and nitrogen supply on the senescence and the retranslocation of nutrients of the oldest leaf of wheat. Ann. Bot. 44:279-287.

Holevas, C.D., D.C. Stylianidis, and Z. Michaelidis. 1985. Nutrient element variability in the leaves of almond trees in relation to variety, rootstock and the vegetative part of the tree. Options Méditerranéennes.

Horst, W.J. and H. Marschner. 1978. Symtome von mangan-uberschuss bei bohnen (phaseolus vulgaris 1.). Z pflanz Bodenk 141:129-142.

Jarrell, W.M. and R.B. Beverly. 1981. The dilution effect in plant nutrition studies. Adv. Agron. 34:197-224.

Kolesch, H., W. Höfner, and K. Schaller. 1987. Effect of bicarbonate and phosphate on ironchlorosis of grapevines with special regard to the susceptibility of the rootstocks. J. Plant Nutr. 10:207-249.

Lambert, H.D., D.E. Baker, and H. Cole. 1979. The role of mycorrhizae in the interactions with zinc, copper and others elements. Soil Sci. Soc. Amer. J. 43:976-980.

Lang, A. 1983. Turgor-regulated translocation. Plant Cell Environ. 6:683-689.

Loneragan, J.F., T.S. Grove, A.D. Robson, and K. 
Snowball. 1980. Phosphorus toxicity as a factor in zinc-phosphorus interactions in plants. Soil Sci. Soc. Amer. J. 43:966-972.

Loneragan, J.F., D.L. Grunes, R.M. Welch, E.A. Aduayi, A. Tengah, D.A. Lazar, and E.E. Cary. 1979. Phosphorus accumulation and toxicity in leaves in relation to zinc supply. Annu. Meeting Fort Collins. Agron. Abstr. p. 175-176.

Loneragan, J.F., D.L. Grunes, R.M. Welch, E.A. Aduayi, A. Tengah, V.A. Lazar, and E.E. Cary. 1982. Phosphorus accumulation and toxicity in leaves in relation to zinc supply. Soil Sci. Soc. Amer. J. 46:345-352

Marschner, H. and I. Cakmak. 1986. Mechanism of phosphorus-induced zinc deficiency in cotton. II. Evidence for impaired shoot control of phosphorus uptake and translocation under zinc deficiency. Physiol. Plant 68:491-496.

Montañés, L., L. Heras, J. Abadía, and M. Sanz. 1993. Plant analysis interpretation based on a new index: deviation from optimum percentage (DOP). J Plant Nutr. 16 (7):1289-1308.

Poling, E.B. and G.H. Oberly. 1979. Effect of rootstock on mineral composition of apple leaves. J. Amer. Soc. Hort. Sci. 104:779-801.

Romera, F.J. and E. Alcántara. 1988. Diferencias entre melocotonero e híbrido melocotoneroalmendro en resistencia a clorosis férrica, $\mathrm{p}$. 429-438. 2nd Simposio Nacional de Nutrición Mineral de las Plantas. I.C.E. Universidad de Granada.

Rosati, A., K.R. Day, and T.M. Dejong. 2000. Distribution of leaf mass per unit area and leaf nitrogen concentration determine partitioning of leaf nitrogen within tree canopies. Tree Physiol. 20:271-276.

Rubio, M.J. and R. Socías i Company. 1991. Posibilidad de hibridaciones dentro del género Prunus L. para la mejora de patrones. ITEA 3:137-148.

Said, A., A. Felipe, and J. Gómez Aparisi. 1993. Patrones híbridos almendro $\times$ melocotonero: Comportamiento en condiciones clorosantes. II Congreso Ibérico de Ciencias Hortícolas, Zaragoza. Actas de Horticultura 9:254-261.

Satdler, J.D. and G.F.A. Lötze. 1990. Yield efficiency and growth of apricot, peach and plum on different rootstocks. Abstracts del XXIII Congreso Internacional de Horticultura, Florencia.

Teng, Y. and V.R. Timmer. 1990. Phosphorus-induced micronutrient disorders in hybrid poplar. I. Preliminary diagnosis. Plant Soil 126:19-29.
Timmer, V.R. and G. Armstrong. 1987. Diagnosing nutritional status of containerized tree seedlings: comparative plant analyses. Soil Sci. Soc. Amer. J. 51:1082-1086.

Timmer, V.R. and E.L Stone. 1978. Comparative foliar analysis of young balsam fir fertilizad with nitrogen, phosphorus, potassium and lime. Soil Sci. Soc. Amer. J. 42:125-130.

Timmer, V.R. and Y. Teng. 1990. Phosphorus-induced micronutrient disorders in hybrid poplar. II. Responses to zinc and copper in greenhouse culture. Plant Soil 126:31-39.

Troyanos, Y.E., N.A. Hipps, J. Moorby and G. Kingswell. 2000. The effect of external potassium and magnesium concentrations on the magnesium and potassium inflow rates and growth of micropropagated cherry rootstocks, 'F.12/1' (Prunus avium L.) and 'Colt' (Prunus avium L. $\times$ Prunus pseudocerasus L.). Plant Soil $225(1-2): 73-82$.

Watanabe, F. and S. Olsen. 1963. Test for determining phosphorus in water and $\mathrm{NaHCO}_{3}$ extracts from soil. Soil Sci. Soc. Amer. Proc. 99:667-668.

Wutscher, H.K. 1989. Alteration of fruit tree nutrition through rootstocks. HortScience 24:578-584. 